Vol. XXII, No. 2

\title{
Sixth Annual Report of the Prairie Nest Records Scheme
}

by Robert Taylor, Regina

During the 1963 nesting season our contributors observed more than 500 nests. Twenty observers submitted 471 nest record cards, some of which contained notes on up to 30 colony nests. These records covered 112 species from Manitoba (61 cards), Saskatchewan (320 cards), Alberta (12 cards), and the Northwest Territories ( 78 cards).

A pleasant surprise was the receipt of 66 cards of 40 species, transferred to us from the Pacific Nest Records Scheme. These records, which had been contributed by Alberta observers between 1957 and 1960, included breeding data on several notable species, for example, Whooping Crane (4 nests), Blue Grouse (1), Rufous Hummingbird (2), Townsend's Solitaire (1), Le Conte's Sparrow (1), and Bufflehead (1). We wish to thank the compiler of the Pacific Scheme, Mr. G. M. McKay. for these additions to our records.

This past year our own contributors had their share of noteworthy records. Most outstanding was David Chandler's nest of a Sage Grouse near Consul, Sask., in the southwest. On May 12 the nest contained 7 eggs. A close second was a Boreal Owl's nest, reported by H. W. Burns of Leduc, Alberta, which was in an old nail keg nest-box erected for Commun Goldeneyes. This nest held 2 eggs and 3 young on May 12; by June 12 the 5 young had left the nestbox. Other notable species from the prairies included: McCown's Longspur (1), Long-billed Curlew (1), and Broad-winged Hawk (1).

Once again an outstanding collection of breeding records was turned in by Ernie Kuyt, a Can. Wildlife Service biologist, stationed at Fort Smith, N.W.T. Ernie's cards, 78 in all, were from the Thelon Game Sanctuary region in the N.W.T., and included such interesting species as: Hoary Redpoll, Gyrfalcon, Peregrine Falcon, Long-tailed Jaeger, Semipalmated Sandpiper, Whistling Swan, Oldsquaw, Northern Phalarope, Semipalmated Plover, and White-fronted Goose.

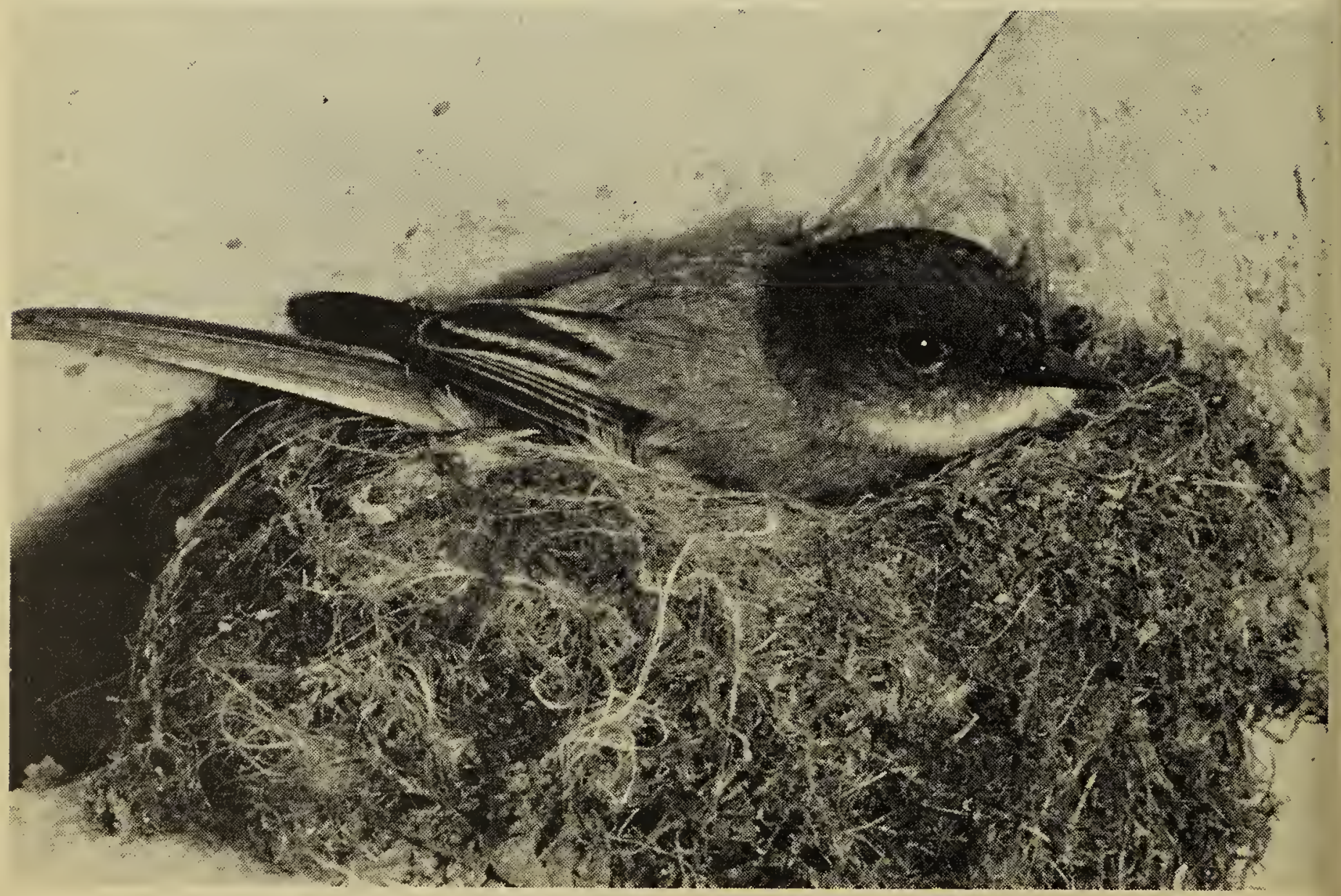


George M. Fairfield of Toronto spent 3 weeks at Moose Jaw doing a study of the behavior and nesting of the Chestnut-collared Longspur. His research yielded 23 record cards, each one of which was filled in fully and included valuable incidental notes. Dr. Robert W. Nero contributed 29 cards from the Lake Athabasca region. These records included a Red-throated Loon's nest and several other northern species. Ross Derkatch of Playmore, Sask., recorded 6 nests of the Long-eared Owl. The largest number of nest record cards for any one species was the 26 cards for the Robin. This was followed by: Chestnut-collared Longspur (24), Brewer's Blackbird (20), Barn Swallow (20), Mallard (19), Red-winged Blackbird (19), and Killdeer (14). All other species had 10 or less cards each.

I would like to thank the following contributors for participating in the scheme in 1963: W. Anaka, F. Brazier, D. Buckle, H. W. Burns, J. D. Chandler, R. Derkatch, G. Fairfield, H. Hedger, E. Kuyt, J. Lane, L. Lohr, S. Mann, Miss M. McGowan, M. McNicholl, Miss D. Meyers, R. W. Nero, Mrs. K. D. Paton, G. J. Smith, E. J. White, and S. Zazalenchuk. I would also like to give a special thanks to Elmer L. Fox who, as chairman of the scheme in the past, has devoted so much time and effort to this activity. Since taking over from Mr. Fox last November I have come to appreciate the amount of effort and care it takes to operate the Scheme.

The 1964 nesting season is now upon us. Throughout this season many members of the Society will undoubtedly discover some birds' nests. We hope that as many as possible will take time to record these for submission on nest record cards. Do not belittle your discovery; even a record of a House Sparrow's nest is useful, particularly if it includes daily observations. I would like to stress again the theme of a recent form letter sent out to all past contributors: safety, accuracy and integrity. The prime concern of any naturalist must be the safety of the nest and its occupants. Scientific accuracy of observations is most important; guessing leads to ambiguity and invalidity. The more information we can get on each nest without losing accuracy, then the more valuable each nest record card will be. If you

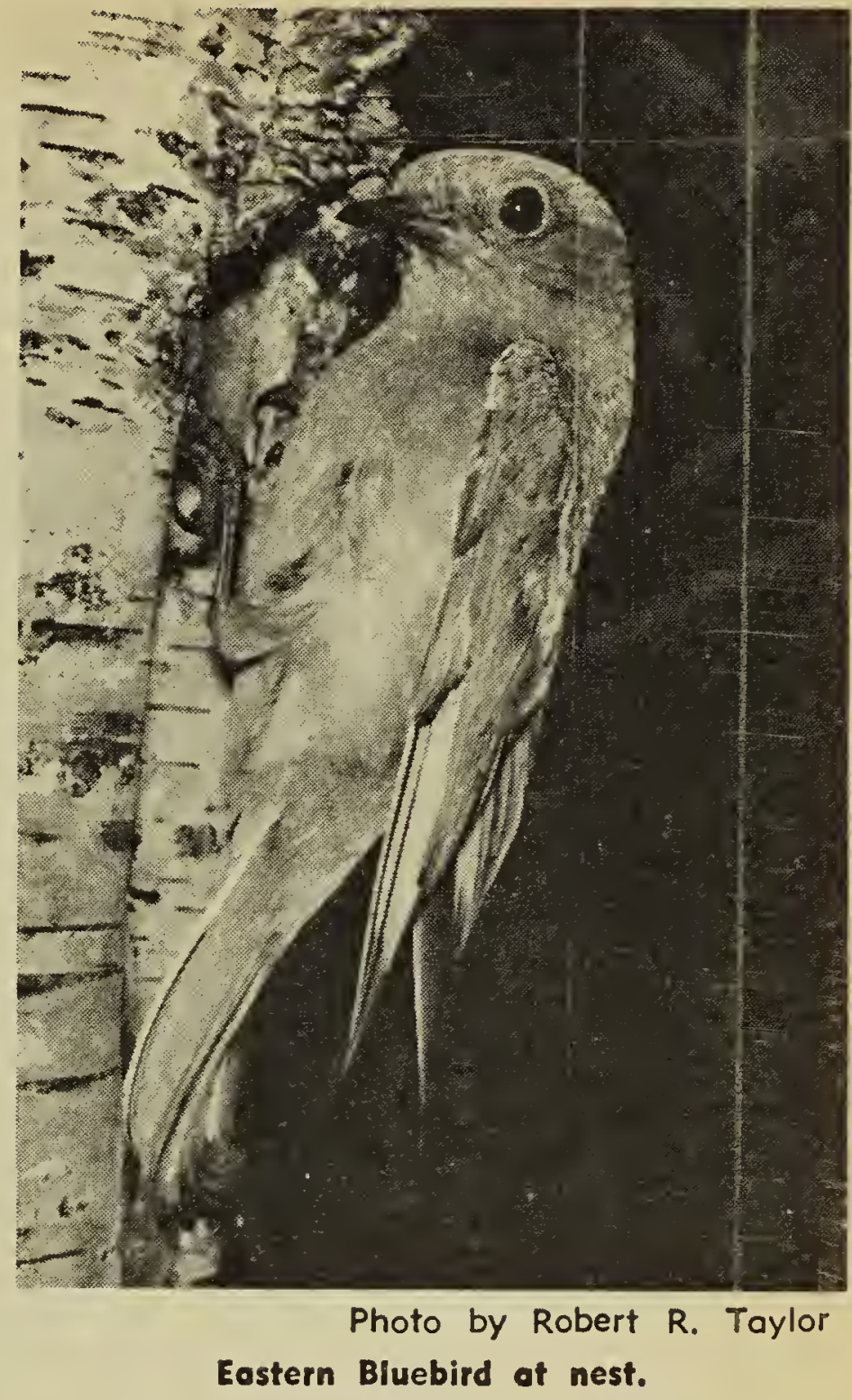

wish a supply of blank cards and/or a copy of the recent form letter, please write to me, as chairman of the Scheme, at: Box 1121, Regina, Saskatchewan.

Species recorded in 1963: Red-throated Loon (1 nest), Horned Grebe (1), Eared Grebe (1) Great Blue Heron (1), American Bittern (1), Whistling Swan (2), Cánada Goose (2), Whitefronted Goose (5), Mallard (19), Pintail (6), Green-winged Teal (2), Blue-winged Teal (3), American Widgeon (1), Canvasback (3), Greater Scaup (13), Oldsquaw (2), Ruddy Duck (1), Red-breasted Merganser (6), Cooper's Hawk (3), Red-tailed Hawk (8), Broad-winged Hawk (1), Swainson's Hawk (1), Rough-legged Hawk (4), Bald Eagle (1), Marsh Hawk (1), Gyrfalcon (1), Peregrine Falcon (6), Pigeon Hawk (1), Sparrow Hawk (1), Ruffed Grouse (2), Sage Grouse (1) Virginia Rail (2), Sora (3), American Coot (9), Semipalmated Plover (3), Killdeer (14), Common Snipe (1), Longbilled Curlew (1), Spotted Sandpiper (1), Semipalmated Sandpiper (1), Marbled Godwit (1), Northern Phalarope (3), Long-tailed Jaeger (1), Herring Gull (3), Common Tern (2), Arctic Tern (5), Black Tern (4); Mourning Dove (10), Black-billed Cuckoo (3), Great Horned Owl (5) Long-eared Owl (9), Short-eared Owl (1), Boreal Owl (1), Common Nighthawk (1), Belted Kingfisher (2), Yellow-shafted Flicker (2), Downy Woodpecker (1), Eastern Kingbird (4), Western Kingbird (5), Eastern Phoebe (5), Say's Phoebe (1), Least Flycatcher (1), Horned Lark (9), Tree Swallow (6), Bank Swallow (1), Barn Swallow (20), Cliff Swallow (10), Black-billed 
Magpie (4), Common Raven (1), Common Crow (5), House Wren (10), Short-billed Marsh Wren (5), Catbird (3), Brown Thrasher (1), Robin (26), Gray-cheeked Thrush (3), Veery (1), Eastern Bluebird (2), Mountain Bluebird (1), Water Pipit (1), Cedar Waxwing (4), Loggerhead Shrike (4), Starling (4), Yellow Warbler (3), Blackpoli Warbler (1), Palm Warbler (1), House Sparrow (2), Bobolink (2), Western Meadowlark (5), Yellow-headed Blackbird (8), Red-winged Blackbird (19), Baltimore
Oriole (3), Brewer's Blackbird (20), Common Grackle (2), Hoary Redpoll (7), Common Redpoll (1), Lark Bunting (6), Savannah Sparrow (4), Vesper Sparrow (10), Slate-colored Junco (1), Tree Sparrow (6), Chipping Sparrow (4), Clay-colored Sparrow (1), Harris' Sparrow (4), White-crowned Sparrow (4), White-throated Sparrow (1), Song Sparrow (10), McCownis Longspur (1), Lapland Longspur (4), Chestnut-collared Longspur (24), Bluebird (1unident.), Kingbird (1-unident.).

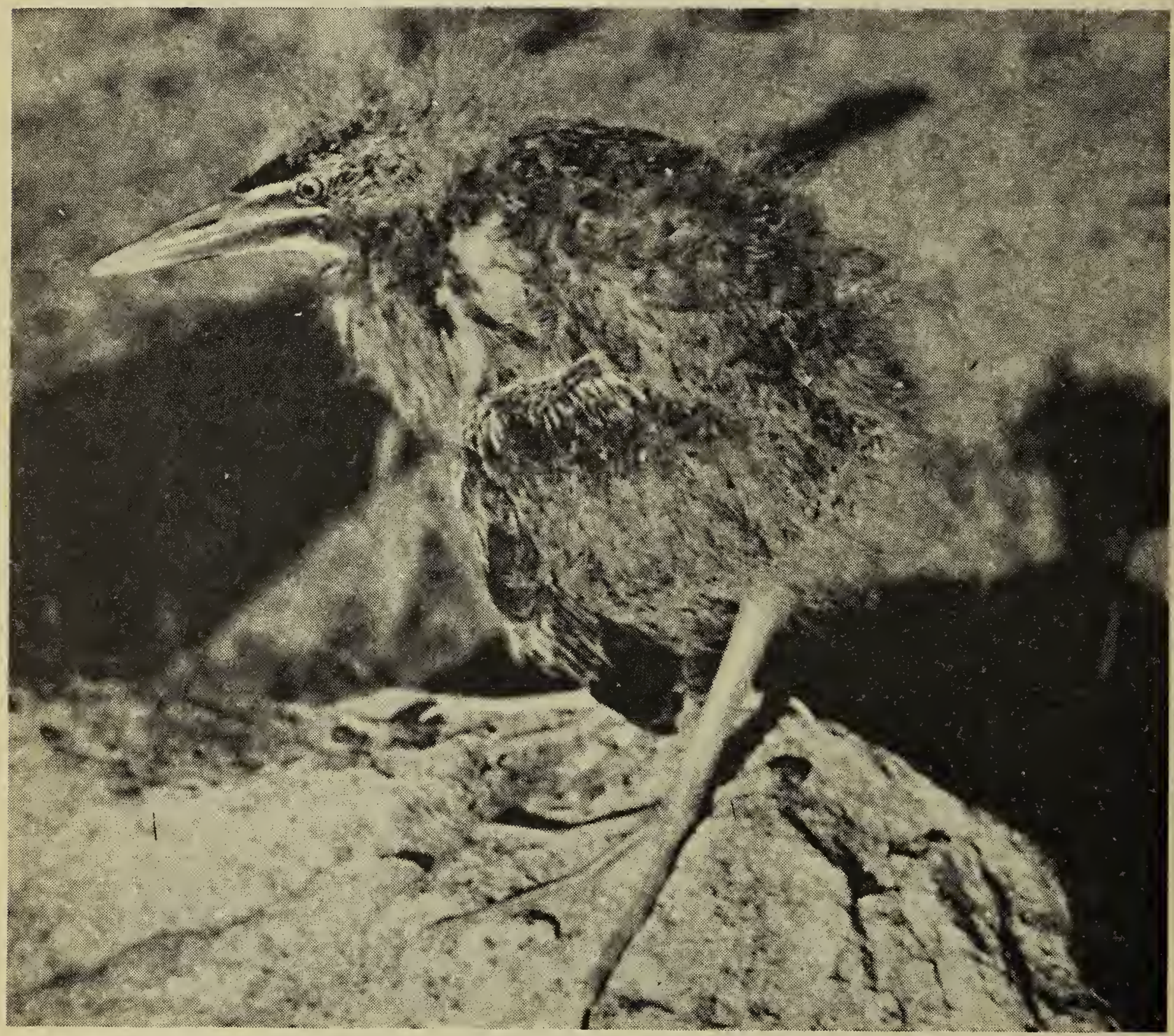

Although there is no record of a nest of the American Bittern in far northern Saskatchewan, the above photograph provides substantial evidence that the species breeds in the region. This flightless juvenile, as reported in the Birds of the Lake Athobosco region, Saskotchewon, was photographed in color by Robert K. Aaberg near Uranium City on July $16,1961$.

\section{SPRUCE GROUSE CORRECTION}

In commenting on Mrs. Hubbard's record of a Spruce Grouse at Grenfell (Blue Jay, 22:5) your hard-working editors overlooked a previous record of this species south of the Boreal Forest; one was seen by Joyce Gunn and photographed by W. J. McDonald at Spirit Lake on November 7, 1954 (Blue Jay, 14: inside back cover).

\section{INFORMATION WANTED}

The Delta Waterfowl $\mathrm{Re}$ search Station is making a study of non-hunting mortality in wild ducks, geese, and swans. If you have notes, or clear re. collections, or if you can take time in the future to make observations for this study please write to the Research Station at Delta, Manitoba, for a questionnaire. 